\title{
DEVELOPMENT OF ECONOMIC EVAPORATIVE AIR COOLING SYSTEM
}

\author{
Sujith K S ${ }^{1}$, Gokul K Manoj ${ }^{2}$, Amal $\mathbf{R}^{3}$ \\ ${ }^{I}$ Department of Mechanical Engineering, BTC College of engineering and technology, Koothattukulam, kerala, India \\ ${ }^{2}$ Department of Mechanical Engineering, BTC College of engineering and technology, Koothattukulam, kerala, India \\ ${ }^{3}$ Department of Mechanical Engineering, BTC College of engineering and technology, Koothattukulam, kerala, India
}

\begin{abstract}
Thermal environmental conditions have very good role in human occupancy and their maximum productivity. Both indoor space conditions and personal factors necessary to provide comfort.it includes the interaction of various parameters like temperature, thermal radiation, humidity, air speed, personal activity level, and clothing Due to global warming ,entire atmospheric conditions are varied very much. temperature level is increasing day by day due to this scenario, this makes uncomfortable for the human beings for doing their jobs with maximum productivity. We are considered our class room where the whole students have been unable to concentrate on their studies due to the uncomfortable room temperature. These will leads to hope of developing an economic evaporative air cooling system in our class room, it will reduce the excessive temperature rise and humidity level in the classroom during the summer. An evaporative cooler produces effective cooling by combining a natural process - water evaporation with a simple, reliable air-moving system. A case study has been done in order to determine the cause of uncomfortable conditions in the class room.
\end{abstract}

Keywords-Thermal comfort, Global warming, Evaporative cooler, Water evaporation

\section{INTRODUCTION}

Human thermal comfort is defined as the conditions in which a person would prefer neither warmer nor cooler surroundings. Thermal comfort depends on both indoor space conditions and personal factors. Indoor space condition will depend on the temperature, humidity, cross ventilation etc.. Personal factors depends on tolerance towards the thermal changes in the atmosphere and clothing etc. [1].recommended level for human comfort is temperature range of $22-27^{\circ} \mathrm{C}$ and humidity level of $55-65 \%$.there are a lot of techniques are used to achieve the thermal comfort. This paper discusses the design and development of an evaporative air cooling system. Low cost and efficiency is the main advantage of these system compared to other conventional cooling system. Evaporative cooler produces maximum cooling when they subject to natural evaporation process by moving water. Evaporative cooling is the most economical and effective means of refrigeration and air cooling since its inception particularly in the areas where climatic conditions are hot and dry[2]. The evaporator cooling technology is an energy-efficient and using onefourth the energy compared to other conventional equipment [3]

\section{CASE STUDY}

Atmospheric condition around a human's living space plays a vital role in his efficiency and also in his health .At present scenario, global warming is the major problem faced by the universe. Room temperature and humidity are the two major factors influencing the comfort level in a room. The effect of outdoor climate influences the indoor condition strongly. The classmates felt uncomfortable during the summer season, especially at the afternoon sessions of lectures due to conditions in the class room. For a detailed study, first of all it was decided to start a data collection of the temperature and humidity levels in the class room during day time at regular intervals. The temperature level and humidity level of the classroom for 30 days duration at the peak summer time has been collected. The result from the data collection was very drastic. The graphical representation of data collection report is plotted below. Below graphs shows that the temperature level reaches up to 39 degrees and relative humidity falls to $39 \%$ during afternoon session .It will cause a lot of health problems in students. The preferred temperature range for occupants dressed in summer clothes is $73^{\circ} \mathrm{F}$ to $79^{\circ} \mathrm{F}\left(22.5^{\circ}\right.$ to $\left.26^{\circ} \mathrm{C}\right)$. Also we face problem of low humidity level. The preferred comfort humidity is 55 to $65 \%$ , but in afternoon sessions the level usually drops to 35 to $39 \%$.This is very drastic and uncomfortable for the students. Low humidity level causes lack of physical harmony in students. We adopted simple techniques for getting comfortable conditions in class room but it did not prove to be effective. So we decided to consider technical aspects in deep and think about alternate methods for tackling this problem. There some alternate techniques illustrated below for getting comfortable conditions in indoor environment. 


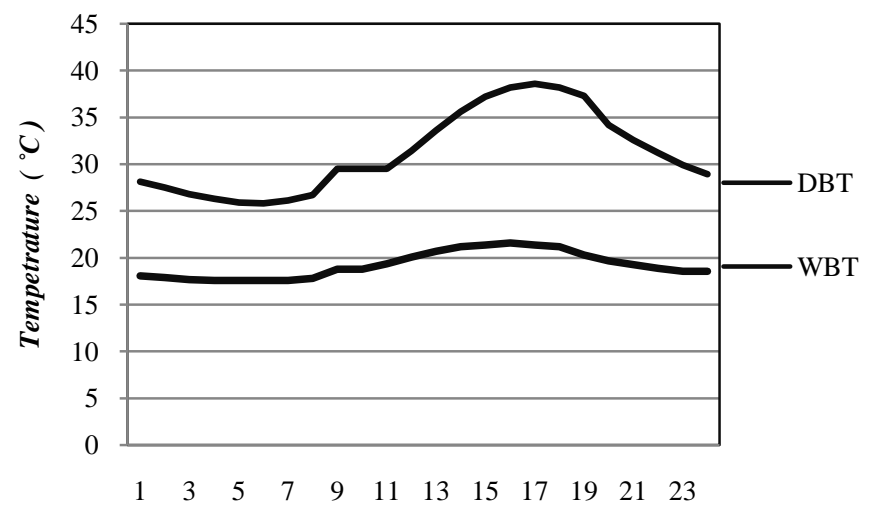

Time (Hours)

Graph 1 .Temperature profile of classroom

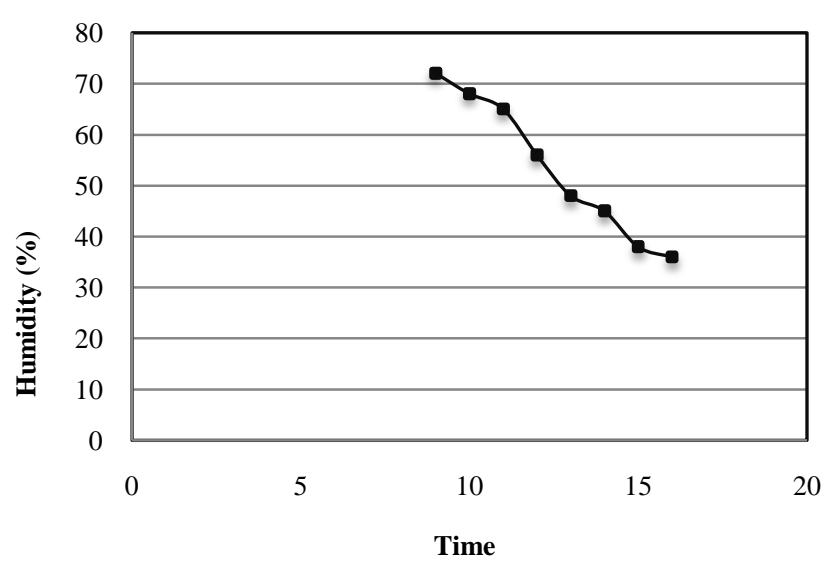

Graph 2 .Humidity profile of classroom

The options that were in front of us for achieving thermal comfort were;
a. Cross ventilation
b. Air conditioning System
c. Exhaust fan
d. Air cooling system

\section{DESIGN FOR EVAPORATIVE AIR COOLING}

\section{SYSTEM}

\subsection{Sensible Heat Removal Sizing Method}

Use the sensible heat load equation to determine the air flow rate:

Where;

Standard cubic feet per minute

$$
S C F M=\frac{\text { Indoor sensible heat gain }(B T U H)}{1.08 \times(I D B-L D B) \times \text { Density Ratio }}
$$

$\mathrm{IDB}=$ Desired indoor (Design) Dry Bulb

LDB $=$ Leaving Dry Bulb from Cooler

\subsection{Heat Load Calculation of Classroom}

Boundry conditions for the classroom are illustrated below ; Outdoor condition : $38^{0} \mathrm{c}, 49 \% \mathrm{RH}, 0.0206$ humidity ratio Design condition $: 27{ }^{\circ} \mathrm{C}, 55 \% \mathrm{RH}, 0.0123$ Humidity Ratio Minimum outdoor temperature $: 32{ }^{\circ} \mathrm{C}$

Daily temperature range $\quad: 7{ }^{\circ} \mathrm{C}$

Effective temperature difference $: 38-27=11^{0} \mathrm{c}$

Wall area

Door area

Window area

$8.6 \times 4 \mathrm{~m}^{2}$

Roof area

$: 1.7 \times .89 \mathrm{~m}^{2}$

$: 1.5 \times 1 \mathrm{~m}^{2}$

$: 8.6 \times 12 \mathrm{~m}^{2}$

\subsection{Estimation of External Loads.}

Table 1. Heat transfer through opaque surfaces

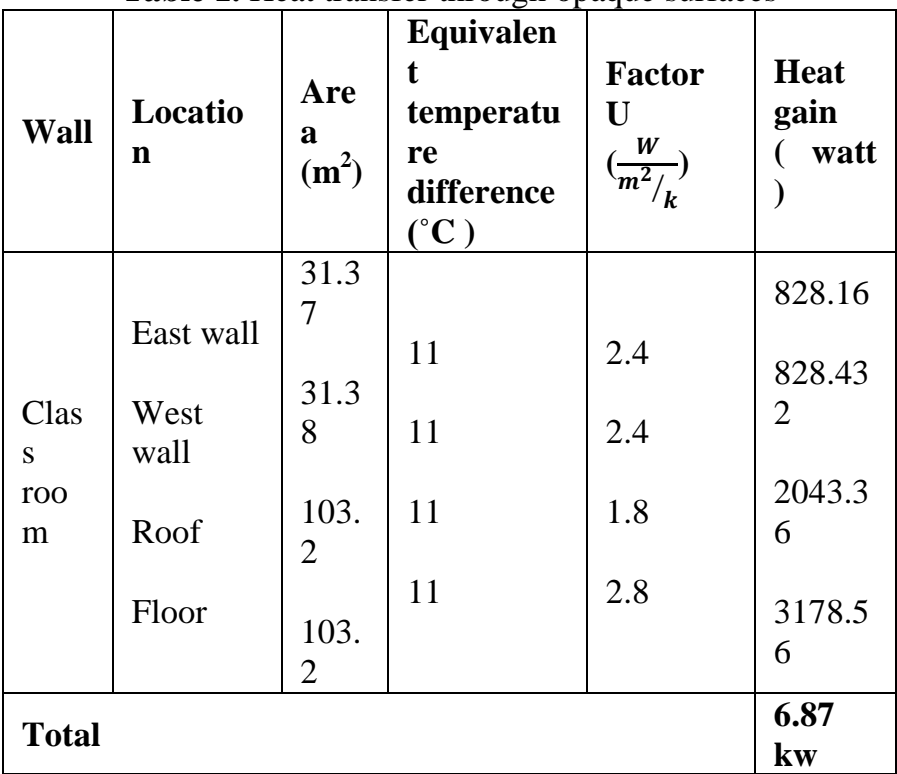

Table 2. Heat transfer through fenestration

\begin{tabular}{|c|c|c|c|c|c|}
\hline Glass & $\begin{array}{l}\text { Locati } \\
\text { on }\end{array}$ & $\begin{array}{l}\text { Area } \\
\left(\mathbf{m}^{2}\right)\end{array}$ & $\begin{array}{l}\text { Equival } \\
\text { ent } \\
\text { tempera } \\
\text { ture } \\
\text { differen } \\
\text { ce } \\
\left({ }^{\circ} \mathrm{C}\right)\end{array}$ & $\begin{array}{l}\text { Facto } \\
\mathbf{r} \mathbf{U} \\
\left(\frac{w}{m^{2} / k}\right)\end{array}$ & $\begin{array}{l}\text { Heat } \\
\text { gain } \\
\text { ( watt ) }\end{array}$ \\
\hline $\begin{array}{l}\text { Windo } \\
\text { W }\end{array}$ & & & & & \\
\hline $\begin{array}{l}\text { Windo } \\
\text { w }\end{array}$ & $\begin{array}{l}\text { East } \\
\text { East }\end{array}$ & $\begin{array}{l}1.5 \\
1.5\end{array}$ & $\begin{array}{l}11 \\
11\end{array}$ & $\begin{array}{l}5.8 \\
5.8\end{array}$ & $\begin{array}{l}95.7 \\
95.7\end{array}$ \\
\hline $\begin{array}{l}\text { Windo } \\
\mathrm{W}\end{array}$ & west & 1.5 & 11 & 5.8 & 95.7 \\
\hline $\begin{array}{l}\text { Door } \\
\text { glass }\end{array}$ & west & 1.5 & 11 & 5.8 & 95.7 \\
\hline \multicolumn{5}{|l|}{ Total } & $\begin{array}{l}0.3828 \\
\text { kw }\end{array}$ \\
\hline
\end{tabular}




\subsection{Heat Transfer due to Infiltration}

Volume of infiltrated air,

$$
\begin{aligned}
& v_{\text {inf }}=\frac{L \times B \times H \times \text { no.of air changes }}{60} \\
& \quad(\text { no. of air changes }=1) \\
& \quad=\frac{12 \times 8.6 \times 4 \times 1}{60}=6.88 \mathrm{~m}^{3} / \mathrm{min}
\end{aligned}
$$

Sensible heat gain due to infiltrated air $=.02044 v_{\text {inf }}\left(t_{1}-\right.$ $\left.t_{2}\right)$

$$
=0.02044 \times 6.88 \times 11=1.54 \mathrm{~kW}
$$

Latent heat gain due to infiltration air $=50 v_{\text {inf }}\left(W_{1}-W_{2}\right)$ $\left(W_{1}, W_{2}\right.$ be the humidity ratios )

$$
=50 \times 6.88 \times(0.0206-0.0123)=2.85 \mathrm{~kW}
$$

Volume of ventilation or outside air $=$

$$
\begin{gathered}
0.28 \mathrm{~m}^{3} / \mathrm{min} / \text { person } \times \text { No. of person }= \\
=0.28 \times 40=11.2 \mathrm{~m}^{3} / \min
\end{gathered}
$$

Outside air sensible heat $=0.02044 v_{\text {vent }}\left(t_{1}-t_{2}\right)$

$$
=0.02044 \times 11.2 \times 11=2.51 \mathrm{kw}
$$

Outside air latent heat $=50 v_{\text {vent }}\left(W_{1}-W_{2}\right)$

$$
=50 \times 11.2 \times(0.0206-0.0123)=4.64 \mathrm{KW}
$$

\subsection{Estimation of Internal Loads}

Sensible heat gain from students

$$
\begin{aligned}
& =Q_{s} \text { per students } \times \text { no. of students } \\
& =59 \times 40=2360=2.3 \mathrm{kw}
\end{aligned}
$$

Latent heat gain from students

$$
\begin{aligned}
& =Q_{l} \text { per students } \times \text { no. of students } \\
& =73 \times 40=2920=2.9 \mathrm{kw}
\end{aligned}
$$

Sensible heat gain due to lighting

total wattage $\times$ use factor $\times$ allowancee factor $(4 \times 60) \times 1 \times 1.25=300=.3 \mathrm{kw}$

Load due to equipment (Fan)

heat gain from one unit $\times$ no. of units

$$
6 \times 116=696 \mathrm{w}=.696 \mathrm{kw}
$$

sensible heat gain due to projector $=225 \mathrm{~W}=.225 \mathrm{~kW}$

Total sensible heat

$$
\begin{gathered}
=6.88+0.3828+1.5+2.51+2.3+.3+0.696+0.225 \\
=14.8 K W
\end{gathered}
$$

Total latent heat $=2.85+4.64+2.9=10.39 \mathrm{KW}$

Total load on the class room $=14.8+10.39=25.19 \mathrm{KW}$

\section{DESIGN AND COMPONENTS USED}

\subsection{Exhaust Fan}

Exhaust fan is used to suck the air from surroundings to cooler for refresh. The design criteria used for exhaust fans in evaporative cooling system is based on air flow in cfm of the classroom. From the calculations we calculated the cfm of the classroom and design size of fan.

$$
\begin{gathered}
\mathrm{cfm}=\frac{\text { room volume }}{\frac{\text { min. }}{\text { change }}}=\frac{39.37 \times 26.24 \times 13.12}{5} \\
\quad 2710.77 \text { For class room min }
\end{gathered}
$$

Air change is $4-6$ per hour

$$
\text { In } \mathrm{m}^{3} / \mathrm{hr}=12 \times 8 \times 4 \times 5=1920
$$

Air volume requirement to meet heat load =

$$
\begin{gathered}
=\frac{\text { TLHS }}{0.9 \times \text { E.F } \times\left(\mathrm{T}_{\text {edb }}-\mathrm{T}_{\mathrm{ldb}}\right)} \\
\text { TLH = total heat load of space (sensible only) } \\
\text { E. F }=2559.9 \\
\text { Tlevation factor }
\end{gathered}
$$

Sensible heat load $=14.8 \mathrm{kw}=50499.69 \mathrm{btu} / \mathrm{hr}$ Specifications

Table 3. Specification of fan

\begin{tabular}{|l|l|}
\hline Size & $380 \mathrm{~mm}$ \\
\hline Power & $105 \mathrm{~W}$ \\
\hline Rpm & 1200 \\
\hline
\end{tabular}

\subsection{Evaporative Cooling Pad}

For system designs to suit the specific needs for your type of building and atmospheric conditions,

For 250 CFM 1 sq. of 4" ft. of pad is used

For 400 CFM 1 sq. of 6" ft. of pad is used

$$
\begin{gathered}
\text { cfm }=\frac{\text { room volume }}{\frac{\text { min. }}{\text { change }}}=\frac{39.37 \times 26.24 \times 13.12}{5} \\
\quad=2710.77
\end{gathered}
$$

Area of evaporative cooling pad required for above $\mathrm{cfm}=$

$$
\frac{2710}{250}=10.84 s q . f t
$$


Table 4. Specification of cooling pad

\begin{tabular}{|l|l|}
\hline Area & $880 \times 770 \mathrm{~mm}^{2}$ \\
\hline Thickness & $100 \mathrm{~mm}$ \\
\hline Material & Cellulose \\
\hline
\end{tabular}

\subsection{Submersible Water Pump}

Table 5. Specification of water pump

\begin{tabular}{|l|l|}
\hline Voltage & $165-250 \mathrm{~V} / 50 \mathrm{~Hz}$ \\
\hline Power & $18 \mathrm{~W}$ \\
\hline Hi-Max & $1.85 \mathrm{~m}$ \\
\hline Output & $1100 \mathrm{~L} / \mathrm{H}$ \\
\hline
\end{tabular}

\section{CONSTRUCTION}

We have tightened the cooling pad to the frame, The frame work was done using a L-Hole bar, It's the skeleton of the air cooling system, The $\mathrm{L}$-Hole frame is used to hold the cooling pad and also the exhaust fan, and it has a main purpose to hold its mechanical vibrations. Another advantage of L-Hole bar is due to the existence of much holes in the bar, its easy to make a frame using it.The overall size of the frame is $86 \times 76 \times 108 \mathrm{~cm}$.

\subsection{Assembly of Exhaust Fan}

Exhaust fan is mounted at the backside of the frame, Its done because of the maximum volume of air have to be circulated through the cooling pad. First we have mounted the exhaust at the center of frame but it was a failure, the volume of air flowing was very low and we couldn't use the entire area of cooling pad.

By use a small pump to circulate the water to the top of cooling pad, A collecting tank made of MS sheet is mounted at the bottom of the air cooler system. A half inch pvc pipe is used to circulate the water through the cooling pad, the small pores are drilled through the pvc pipe in a distance .5 $\mathrm{mm}$.We have insulated the air cooling system thermally using a polycarbonate sheet, It's because its thermally non conducting material. By using this material the weight of the material can be reduced to a high extent. The insulation is done air tightly; There will not be any leakage of air. And the polycarbonate material is available at cheap rate. So its economically feasible one

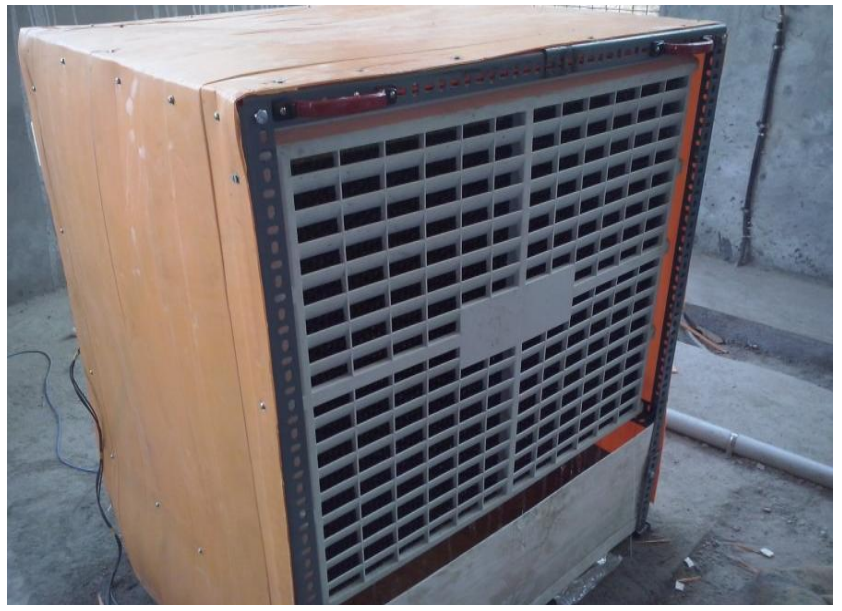

Fig 2: Fabricated evaporative cooling system

\section{CONCLUSION}

Table 6 .comparative study 1

\begin{tabular}{|c|c|c|c|c|c|c|c|c|}
\hline & & $\begin{array}{l}9.0 \\
0 A \\
M \\
\end{array}$ & $\begin{array}{l}10 . \\
00 \\
\text { AM } \\
\end{array}$ & $\begin{array}{l}11 . \\
00 \\
\text { AM }\end{array}$ & $\begin{array}{l}12 . \\
00 \\
\text { AM } \\
\end{array}$ & $\begin{array}{l}1.0 \\
0 P \\
M\end{array}$ & $\begin{array}{l}2.3 \\
0 \mathbf{P} \\
\mathrm{M} \\
\end{array}$ & $\begin{array}{l}4.0 \\
0 P \\
M \\
\end{array}$ \\
\hline \multirow{2}{*}{$\begin{array}{l}\text { Day } \\
\text { befor } \\
\text { eplac } \\
\text { i-ng } \\
\text { ECS }\end{array}$} & $\begin{array}{l}\text { Temp. } \\
\left({ }^{\circ} \mathrm{C}\right)\end{array}$ & 32 & 34 & 35 & $\begin{array}{l}35 . \\
6\end{array}$ & 36 & 36 & 38 \\
\hline & $\begin{array}{l}\text { humidi } \\
\text { ty } \\
(\%)\end{array}$ & 72 & 65 & 56 & 48 & 45 & 38 & 36 \\
\hline \multirow{2}{*}{$\begin{array}{l}\text { day } \\
\text { befor } \\
\text { e } \\
\text { placi- } \\
\text { ng } \\
\text { ECS }\end{array}$} & $\begin{array}{c}\text { Temp. } \\
\left({ }^{\circ} \mathrm{C}\right)\end{array}$ & 32 & 30 & 30 & 31 & 31 & 30 & 29 \\
\hline & $\begin{array}{l}\text { humidi } \\
\text { ty } \\
(\%)\end{array}$ & 68 & 60 & 54 & 53 & 50 & 49 & 49 \\
\hline
\end{tabular}

Table 7 .comparative study 2

\begin{tabular}{|l|l|l|l|l|}
\hline & & & & \\
$\begin{array}{l}\text { Particula } \\
\text { rs }\end{array}$ & & & & \\
\hline $\begin{array}{l}\text { Cost } \\
\text { consumpt } \\
\text { ion/hr }\end{array}$ & 3.5 & 0.105 & 0.256 & 0.123 \\
\hline $\begin{array}{l}\text { Installati } \\
\text { on }\end{array}$ & Difficult & Difficult & Easy & Easy \\
\hline $\begin{array}{l}\text { Sound } \\
\text { pollution }\end{array}$ & Lowest & High & Less & less \\
\hline $\begin{array}{l}\text { Temperat } \\
\text { ure drop }\end{array}$ & High & Low & Low & Low \\
\hline
\end{tabular}


In this project a low cost evaporative cooling system has been designed. The main objective of this project was to increase the humidity level and to decrease the temperature level of the class room. And we have achieved our objective economically. And after installing the Air cooler system inside the classroom the temperature level decreased to $7^{\circ}$. And the humidity of the classroom increased by $18 \%$.So that the low cost evaporative cooling system is a success. While comparing with the Air Conditioning systems available in India it costs about Rs17000 for a 1 ton ac which is suitable for only a 900 sq. ft. room, Where as our air cooling system can be used for a room of 1500 sq. ft. and the cost is very low compared to the air conditioning system .This evaporative air cooling system can be used in the rural areas of India where the humidity in the air is very low. The effectiveness of this evaporative air cooling system can be improved by making some changes in the design process. Since we had some limitations exists as it's a first venture of us.

\section{REFERENCES}

[1] Poonia M.P., Bhardwaj A., Upender Pandel, JethooA.S., "Design and Development of Energy Efficient Multi-Utility Desert Cooler," Universal Journal of Environmental Research and Technology, Vol 1 39-44, 2011.

[2] Sirelkhatim K. Abbouda, and Emad A. Almuhanna, "Improvement of Evaporative Cooling System Efficiency in Greenhouses," International Journal of Latest Trends in Agriculture \& Food Sciences, Vol-2 No 2 June 2012.

[3] Zhang Ala Hasan, "Performance Investigation of Plain and Finned Tube Evaporatively Cooled Heat Exchangers," Applied Thermal Engineering, Elsevier Science Ltd, 2003.

[4] J R Camargo, "Evaporative cooling: water for thermal comfort,- An Interdisciplinary," Journal of Applied Science.

[5] S. S. Wane and M. B. Nagdeve, "Design of air cooling system for college auditorium," Journal of Environmental Research And Development, Vol. 6 No. 3, Jan-March 2012

[6] Vivek W. Khond, "Experimental investigation of desert cooler performance using four different cooling pad materials," American journal of scientific and industrial research, 2011, 2(3): 418-421

[7] J.R.Camargo, "Evaporative Cooling Water for Thermal Comfort", An Interdisciplinary Journal of Applied Science Vol 3,No4: pp.51-61, 2008.

[8] Evaporative air conditioning handbook - Watt, Brown - 1997 . 